\title{
Vidas Precárias em Águas Turvas: antropologia colaborativa nas ruínas do Antropoceno
}

\author{
Thiago Mota Cardoso ${ }^{1}$ \\ Cristiana Losekann ${ }^{2}$ \\ Rafael Buti ${ }^{3}$ \\ Pedro Castelo Branco Silveira ${ }^{4}$ \\ Natalia Seeger ${ }^{5}$ \\ Diego Kern Lopes ${ }^{2}$ \\ ${ }^{1}$ Universidade Federal do Amazonas, Manaus, AM, Brasil \\ ${ }^{2}$ Universidade Federal do Espírito Santo, Vitória, ES, Brasil \\ ${ }^{3}$ Universidade da Integração Internacional da Lusofonia Afro-Brasileira, São Francisco do \\ Conde, BA, Brasil \\ ${ }^{4}$ Fundação Joaquim Nabuco, Recife, PE, Brasil \\ ${ }^{5}$ Artista e Pesquisadora Independente, Florianópolis, SC, Brasil \\ O artigo apresenta cinco relatos de experiências de pesquisas colaborativas em contextos de águas turvas e \\ ruínas do Antropoceno. Os contextos são de barragens rompidas e de outras em construção, de manguezais \\ sofrendo pelas políticas assimétricas de gestão e de outros que sofrem pelos empreendimentos de petróleo. \\ Jardins e terra também são contextos que surgem em meio a esses relatos como alternativas e resistências. \\ Em meio às águas de rios, de mares e de manguezais, emergem diferentes propostas de experiências \\ de colaboração entre pesquisadores e comunidades, sejam estas de humanos ou de não humanos. Em \\ comum, os relatos trazem a importância da reflexividade para o pesquisador, da interdisciplinaridade, \\ da necessidade de métodos inovadores e das práticas de troca dos pesquisadores com as comunidades \\ estudadas e com os públicos que recebem as pesquisas.
}

\section{Resumo}

Palavras-chave: Paisagem em Ruína. Antropoceno. Antropologia da Água.

\section{Precarious Lives in Muddy Waters: collaborative anthropology in the ruins of the Anthropocene}

\begin{abstract}
The article presents five reports about collaborative research experiences in contexts of muddy waters and ruined ruins in the Anthropocene. The contexts are dams disaster and construction, mangroves suffering from asymmetric management policies and others suffering from oil ventures. Gardens and land are also contexts that appear in the midst of these reports as alternatives and resistances. Amid the waters of rivers, seas and mangroves, different proposals for collaborative experiences between researchers and communities, whether human or non-human, emerge. In common, the notices bring the importance of reflexivity of the researcher, interdisciplinarity, and the need for innovative methods and exchange of practices with the communities studied and with the audiences that receive the research.
\end{abstract}

Keywords: Ruined Landscape. Anthropocene. Anthropology of Water. 


\section{Introdução}

Precisamos de histórias (e teorias) amplas o suficiente para reunir as complexidades e manter as fronteiras abertas e insaciáveis por novas e surpreendentes conexões. (HARAWAY, 2016, p. 101)

$\mathrm{E}$ ste artigo experimental, escrito em várias mãos, é fruto das reflexões que nos entrelaçaram durante a Oficina de Pesquisa “Águas turvas, vidas precárias: pesquisas colaborativas sobre a arte de conviver no Antropoceno", ocorrida durante a VII Reunião da Antropologia da Ciência e da Tecnologia (ReACT). A oficina consistiu em encontros entre pesquisadores e artistas engajados em diferentes situações na produção etnográfica sobre questões ambientais. Estes relataram e refletiram sobre diferentes modos de fazer pesquisa colaborativa em situações de intensa precarização de vidas, corpos e paisagens. Colaboração, palavra-chave em nosso estar juntos e recorrente na antropologia, era a arte de conviver e de fazer juntos a diferença (CHOY et al., 2009; RAPPAPORT, 2008).

A água nos entrelaça. A água é o personagem principal, trazido ao primeiro plano nas histórias que serão narradas como em um mosaico multivocal sobre nossas pesquisas colaborativas por meio da antropologia das águas (BALLESTERO, 2019). Descreveremos as águas turvas e as vidas precarizadas nos estuários, rios e nos manguezais devastados pelas usinas de cana-de-açúcar, pelo petróleo e pelo cercamento das terras no Recôncavo da Bahia e no Rio Goiana em Pernambuco; as águas contaminadas e as vidas arrasadas pelo desastre do rompimento das barragens da mineradora Vale, em Minas Gerais; as águas ameaçadas e catástrofes imaginadas em decorrência da construção de hidrelétricas no Idixidi, o Rio Tapajós no Pará; e as águas turvas pela alquimia de plantas, compostos, metais e tecido. Entrelaçamos heterogêneas abordagens de pesquisa e a multiplicidade de vidas e situações em uma história comum - dos habitantes de mundos em ebulição atingidos pelas disruptivas forças antropocênicas dos imperialismos industriais e de ecologias simplificadoras das plantations.

A precarização nos desafia. Desastres, devastações, conflitos, choques, violências e resistências colaboram para compreendermos lugares precarizados e vidas vulnerabilizadas (HINKSON, 2017). Interconectamo-nos por meio de nossas experiências colaborativas de pesquisa, ensino e extensão em diferentes circunstâncias socioecológicas e de participação política, em situações de precarização de existências, diante de processos de desenvolvimento, ou do que vem sendo chamado de Antropoceno. Essas rupturas e precarizações de vidas humanas e não humanas, e de paisagens, vêm provocando a antropologia em experimentar etnograficamente o tema do Antropoceno e, ao mesmo tempo, em questionar as pretensões dualistas, universalistas das engenharias globais 
hegemônicas que esse conceito-práxis evoca (HARAWAY et al., 2016). O que a antropologia pode dizer, então, sobre o Antropoceno ou, como preferimos, sobre as forças antropocênicas e suas infraestruturas na paisagem? Como a antropologia pode se debruçar sobre as forças transformadoras e precarizadoras das vidas na terra e, ao mesmo tempo, poder contar histórias outras sobre a recuperação e a cura? (MATHEWS, 2020). São essas as premissas de base para as contribuições que podemos aportar acerca do ponto de vista antropológico sobre o Antropoceno (ou se preferirem o Capitaloceno ou o Plantationoceno), como parte da compreensão das existências em tempos de catástrofes (STENGERS, 2015).

"Antropoceno" é um termo proposto para a nova época geológica no qual a ação humana vem sobrepondo e colapsando muitos corpos, paisagens, atmosfera e modos de vida, marcando as estruturas geofísicas locais e globais. O Antropoceno é um termo perigoso, um presente venenoso (poison gift) para o mundo e para a Antropologia, como diria Bruno Latour (2017). Um presente que nos permite repensar radicalmente o "antropos" e que vem sendo posto em relevo de forma diferente, agora como força geológica. Veneno, pois dissolve o humano ao fetichizá-lo. Essa ambiguidade do termo nos faz pensar o mundo como se fossemos Homens-acima-da-terra, um problema da espécie, o Homo sapiens genérico que, além de não incluir a malha multiespécie em suas histórias, borra a interseccionalidade das diferenças étnicas, raciais, de classe e de gênero (MATHEWS, 2020; KRENAK, 2019; HARAWAY, 2016; TSING, 2019). Portanto, não seria o Antropoceno (o tempo do Antropos) o responsável pela situação catastrófica de nossos tempos, mas sim a cena da supremacia masculina branca, ou a linha divisória geológica de cor, gênero e classe (MIRZOEFF, 2018). O que nos faz perguntar: "Antropoceno para quem?".

Mesmo diante das críticas ao termo, buscamos dar um uso produtivo ao "Antropoceno" (MATHEWS, 2020). Nesse sentido, concordamos com Anna Tsing (2019), quando ela defende a necessidade de explorarmos as contradições inerentes ao conceito, e de nele adentrarmos para contar histórias dos limites da excepcionalidade humana e suas consequências não intencionais nos modos de vida dos muitos povos que habitam a Terra (DANOWSKI; VIVEIROS DE CASTRO, 2014). Anna Tsing nos inspira a manter o termo, porém distanciando produtivamente de seu uso corrente: como antropos, esse "humano moderno", como o "Man" supostamente conquistador da natureza. O Antropoceno não se refere ao Humano, mas a um particular tipo de humano inventado no iluminismo (TSING, 2019).

Outra torção é necessária se quisermos usar produtivamente o termo Antropoceno em nossas experiências: refere-se ao abandono de sua versão totalizante, que descreve a terra como um espaço unificado, no sentido que dão as teorias sistêmicas (HARAWAY et al., 2016). É preciso, ao invés disso, mergulharmos etnograficamente nas "manchas antropocênicas" (TSING; MATHEWS; BUBANDT, 2019), compreendendo que as transformações ambientais como o aquecimento global, arruinamento de paisagens e as extinções massivas das espécies são localizadas e diferencialmente produzidas e sentidas. Ao nos determos cuidadosamente nas manchas antropocênicas, podemos testemunhar como as infraestruturas emergem nas paisagens a partir de ruínas produzidas pela indústria e pela plantation e, assim, descrever como os conflitos entre modos de existir e sensibilidades se apresentam em fraturas entre aqueles que ainda são capazes de se 
satisfazer com a terra, e aqueles que projetam transformá-la, mecanizá-la ou até mesmo abandoná-la (GLOWCZEWSKI, 2015).

Durante a oficina nos colocamos diante das seguintes questões: como humanos e outras espécies compartilharão mundos em comum? Como (r)existir ao/no "tempo das catástrofes", trazendo a público relações silenciadas? Como podemos fazer pesquisas, extensão e ensino de forma colaborativas e que rompam com o dualismo entre natureza e cultura e com o excepcionalismo humano que subsiste tanto nas narrativas acadêmicas quanto nos projetos de desenvolvimento capitalista produtores de ruínas? Qual é a contribuição da Antropologia, da universidade pública e da pesquisa engajada nesses cenários? Como podemos nos valer de novos aportes metodológicos que melhor traduzam os sentidos e as perspectivas locais? Tratamos dessas questões com cinco testemunhos, no afã de que este encontro sobre colaborações pudesse nos dar a oportunidade de animar nossas práticas e nossas ações (KRENAK, 2019). Vamos a elas.

\section{Nas Águas do Rio Doce, Mecanismos Poéticos, Experiências e Reviravoltas de Pesquisa no Processo-Catástrofe de Mineração ${ }^{1}$}

Quando saímos, no dia 2 de dezembro de 2015, em uma expedição, junto com outros pesquisadores, para ver o que a ruptura da barragem de Fundão em Minas Gerais havia provocado nos pequenos vilarejos e cidades no Espírito Santo não imaginávamos que iniciaríamos uma longa e difícil caminhada na qual não estaríamos sozinhos e construiríamos uma nova maneira de pesquisar.

Essa experiência de pesquisa em extensão começa com as arenas públicas itinerantes realizadas em comunidades atingidas pelo desastre-crime da Samarco, Vale e BHP Biliton, causado pelo rompimento da barragem de mineração de Fundão, MG. As arenas foram realizadas durante quatro dias ao longo da bacia do Rio Doce e litoral do ES, no ano de 2017, e tiveram como proposta discutir os efeitos do desastre nas comunidades, os desafios para a mobilização social comunitária frente às grandes empresas e os desejos de reparação das comunidades. O trabalho, desde sua concepção, suscitou vários questionamentos: sobre os limites entre o fazer conhecimento a partir da universidade e a partir de outras posições sociais; sobre as formas de escutar as comunidades e o uso de materiais inusitados como fontes de pesquisa; sobre as responsabilidades da universidade ao entrar e propor atividades em comunidades e suas territorialidades. Tal experiência culminou no Projeto "Mecanismos poéticos para projetos utópicos" que desenvolve a reflexão sobre o desastre junto com o campo da arte.

A primeira coisa que precisa ser dita sobre entrar em um processo de catástrofe é que nada é tranquilo aí. O ritmo é frenético, as interações são muitas, diversas e intensas, somos convocados a agir. Não há lugar de contemplação, e quem quer contemplar não fica imune às críticas. Parte do processo envolve assumir um lado, afinal trata-se de narrar uma relação de causalidade destruidora, com atores completamente assimétricos e pessoas em situação de violação grave de direitos. Até hoje, não se pode dizer que houve real reparação: as famílias não foram reassentadas em Minas Gerais, dos 21

${ }^{1}$ Capítulo elaborado por Cristiana e Diego. 
territórios apenas três conquistaram sua principal reivindicação, que é a assessoria técnica aos atingidos. Além disso, existem múltiplas dimensões irreparáveis: as toneladas de peixes não ressuscitarão, o rejeito não sairá do rio, se for tirado também haverá danos, ninguém pode garantir que o rio se recuperará. Além do abalo das interdições múltiplas nos modos de vida, uma cadeia de relações tortuosas se estabeleceu entre os diferentes atores nesse processo.

Os territórios afetados foram inundados também por pessoas querendo "fazer alguma coisa", entre elas, cientistas de todas as áreas. A presença de pesquisadores e de práticas técnico-científicas também compõe os efeitos desse processo-catástrofe. A proliferação de atores diversos nos territórios provocou assédios morais de diversos tipos, mas inclusive algo que podemos caracterizar como "assédio científico" por insistência impertinente na obtenção de dados e de coletas de materiais para pesquisa sem seguir os protocolos básicos de ética em pesquisa, mas também sem demonstração de uma preocupação com a compreensão mais abrangente da catástrofe. Por tudo isso, as populações afetadas desenvolveram muitas desconfianças sobre as atividades técnico-científicas. Isso se reflete também em certo descrédito com a própria reparação e com processos em que a participação das pessoas é requerida. Todos querem o engajamento dos atingidos em tudo quanto é tipo de atividades, de decisão, de consulta, de legitimação e de coleta. Nesse sentido, o excesso de técnicos nos territórios, as inúmeras ações envolvendo a população e a introdução de práticas participativas diversas produziram uma espécie de fadiga, já que foram se multiplicando a quantidade de reuniões e as técnicas sugeridas para manifestação do pensamento e da vontade, tudo isso somado a um esvaziamento de sentido.

Nesse cenário de percepções, também fomos nós ficando preocupados com as possibilidades de estarmos transtornando essas vidas atingidas pelo desastre. Importante dizer que nós trabalhamos em um grupo grande com pesquisadores em diferentes estágios de formação (graduação, mestrado, doutorado e professores), áreas do conhecimento diversas ( Sociologia, Antropologia, Ciência Política, Direito, Artes, Psicologia, Geografia, etc.).

Nessa confrontação com outros grupos de pesquisa, um dos nossos primeiros questionamentos foi exatamente com relação ao número de pessoas em campo. Isso não estava bem. Precisávamos repensar, selecionar melhor as parcerias e, mesmo dentro do grupo, repensar quem de fato teria condições de assumir a responsabilidade que é se deixar ser afetado pela catástrofe. A partir desse problema, iniciamos profundas e desconfortáveis discussões sobre como e por que faríamos campo, sintetizadas em um princípio da instabilidade total a partir da permanente questão: Somos realmente diferentes dos outros grupos de pesquisa? Em outro nível desse problema e já em um esforço de resposta, chegamos ao compromisso com princípio da honestidade, principalmente quando nos deparamos com as seguintes questões: Como responder às demandas das comunidades? Até que ponto podemos garantir que nossas pesquisas produzam efeitos positivos para as comunidades? A honestidade nos obrigava a admitir que não possuímos controle total do nosso trabalho, já que, muitas vezes, podem ocorrer efeitos adversos não imaginados, ou que podemos errar - o que evidentemente não nos exime de uma ação refletida e responsável. Daí o princípio da responsabilidade, ou seja, estarmos cientes de que sempre teremos que responder aos nossos atos. 
Um momento de campo marcante para esse processo de construção da colaboração científica foi o dia em que o barulho do "cleck" dos obturadores das máquinas fotográficas nos incomodou. Assim, iniciamos um estudo com o suporte das discussões da arte conceitual sobre o porquê de a imagem ser ou não relevante e sobre os problemas e riscos da estetização do desastre. Refletimos que o registro dentro de uma perspectiva crítica e acadêmica deveria ser muito questionado e precisaria ser justificado de maneira plural nos diversos campos disciplinares nos quais nos inserimos como grupo de pesquisa. Ou seja, o princípio da plurijustificação implicava ter que efetivamente dialogar com os problemas teóricos e o estado da arte do campo do colega-pesquisador ao lado. Nos casos que envolvem todos os tipos de registro audiovisuais, buscamos discutir a justificação com a arte contemporânea. Assim, limitamos o número de máquinas, reduzimos o tamanho delas e nos provocamos a refletir sobre o que e de como registrar.

\subsection{Das Arenas Públicas aos Mecanismos Poéticos para Projetos Utópicos}

Nós realizamos, entre os dias 16 e 19 de novembro, uma Arena Itinerante com o tema "Grandes Empreendimentos e o Desastre da Samarco". Nesse momento específico, a arena fazia parte de um processo de formação de defensores populares da participação e de direitos e teve como objetivo discutir os desafios dos atingidos na construção da mobilização e no acesso à justiça. Os objetivos foram definidos a partir das experiências anteriores de investigação sobre os efeitos socioambientais de grandes projetos de desenvolvimento e construídos em parceria com os atuais atores com os quais estamos trabalhando, principalmente, ligados ao processo de mobilização em torno do desastre-crime da Samarco no Rio Doce.

A ação de extensão foi programada durante meses, nos quais a equipe pensou sobre as metodologias participativas. Refletimos, também, sobre os aspectos da captação e o uso das imagens, discutindo sobre por que, para que e como coletá-las.

Além dos atingidos, foram convidados diferentes atores já engajados em debates sobre o desastre-crime provocado pela mineradora Samarco, ou, atores que debatem mineração em outros territórios. Ao longo do percurso, foram propostas pequenas arenas de debate em torno da questão do desastre e dos grandes empreendimentos, e as pessoas foram convidadas a se expressarem por meio de diferentes dinâmicas: escrevendo e/ou desenhando em tarjetas. Em todos os lugares, com pequenas variações, nós propomos que as pessoas falassem das suas percepções sobre os impactos e os desafios das mobilizações após a ruptura da barragem - por meio da ideia de "denúncias" e de "anúncios". As comunidades discutiram, denunciaram e se expressaram de muitas maneiras que foram registradas de formas diversas (relatorias escritas e audiovisuais). Em todos os momentos houve também espaço para alimentação, descontração, música e para as conhecidas "místicas" típicas dos movimentos sociais. A fala era livre, mas em todos os espaços as pessoas eram convidadas a refletirem sobre sua conduta: se permitia a igualdade de gênero, étnico-racial, geracional, ou simplesmente se elas atentavam para o tempo da sua fala. As crianças participaram de diversas formas: desenharam, falaram, escreveram, 
ou simplesmente brincaram durante a atividade. Os animais também puderam ficar presentes, e o ambiente de realização das arenas foi escolhido por cada comunidade, havendo espaços abertos (beira do rio), salas de associações comunitárias, praças ou quadras de esportes.

O processo todo da arena durou quatro dias e envolveu todos os que transitaram pelos territórios e cada comunidade particularmente. Em cada pequena arena local, os atores externos foram convidados a se apresentarem e contarem sobre suas próprias vivências e lutas nos seus locais de origem ou relacionadas aos seus ofícios. A ideia era provocar a criação de experiência singular no sentido de Dewey (2005) na vida de todos os participantes, entendendo que a troca de experiências, e, sobretudo, o convívio durante tantos dias e por meio da experimentação de coisas comuns, podem construir conhecimento, formar o pensamento e produzir novas práticas. Durante a arena todos estavam em formação, e, a não ser por distintas responsabilidades, a hierarquia típica da universidade não era um princípio definidor das decisões e das relações.

Para além dos objetivos típicos de uma atividade de extensão, na qual nós construímos juntos um processo com as comunidades afetadas, levando em consideração as questões teóricas que norteiam o debate dos movimentos sociais e das teorias da democracia, a atividade também foi geradora de conhecimento. Ao longo do percurso conhecemos a realidade de comunidades que foram atingidas pela lama da Samarco e que são historicamente impactadas por grandes empreendimentos extrativos. Por meio das diferentes formas de relatoria, nós produzimos a identificação de efeitos da lama nas vidas das comunidades e pudemos compreender os desafios dos processos de mobilização social. Além disso, entendemos que havia a necessidade de criar uma nova forma de comunicar tudo o que havíamos vivido nesta pesquisa.

\subsection{O Mecanismo Poético “tensão"}

A obra "tensão" (Figura 1) é uma ação poética artística e de pesquisa em arte baseada exatamente nessa vontade de criar algo além de artigos e comunicações científicas. Ela foi concebida e produzida no contexto da pesquisa sobre o desastre no rio. Nesse processo foram realizados registros audiovisuais diversos e uma profunda reflexão sobre as funções e as disfunções desse tipo de registro. 


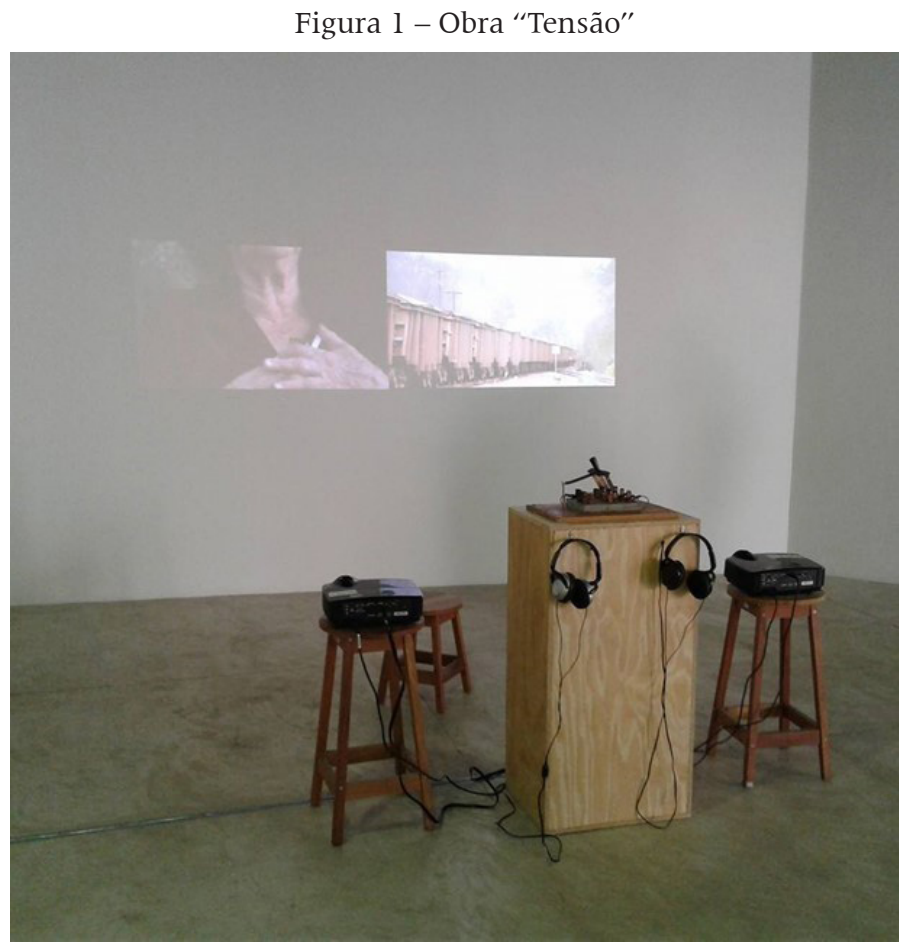

Fonte: Produzida pelo artista-pesquisador Diego Kern Lopes

Na obra apresentam-se, então, os registros dos depoimentos das populações ribeirinhas atingidas, assim como os registros da intensa movimentação dos trens da empresa Vale que transportam o minério de ferro extraído em Minas Gerais para ser exportado pelo porto de Tubarão em Vitória, ES. A exposição do trabalho consiste na projeção de ambos os registros, lado a lado. Entretanto, o áudio desses depoimentos é coordenado por uma alavanca situada entre os dois projetores. A alavanca, em sua posição de repouso garantida por uma mola, transmite somente o áudio - avassalador dos trens. Para escutar o áudio dos depoimentos dos atingidos, o público deve acionar a alavanca tensionando, dessa forma, a mola. Esse tensionamento faz com que o espectador seja envolvido (afinal é preciso, além de deliberar, manter de forma física a deliberação do acionamento) no depoimento dos atingidos. Dessa forma, assim como o corpo dos atingidos pelo desastre, o corpo dos espectadores também é afetado nesse processo. A ação artística consiste na instalação desse mecanismo em diversos espaços, na produção de novos registros e na divulgação da situação dos atingidos.

Tendo em vista o Organon - Núcleo de ensino, pesquisa e extensão em mobilizações sociais é um grupo de pesquisa interdisciplinar, com pesquisadores das ciências sociais, arte, direito e geografia - foi fundamental construir uma reflexão sobre o campo e as produções das pesquisas, incluindo um debate longo sobre o uso da imagem, do som e das formas de comunicar as reflexões que motivam nossas pesquisas. Durante todas as nossas incursões nas comunidades afetadas por esse desastre, um dos nossos desafios era romper o som do trem da Vale que produz um som ensurdecedor e corta grande parte dessas comunidades afetadas. Assim, nossa dificuldade de literalmente escutar as falas dos atingidos se assemelha à dificuldade que essas pessoas enfrentam historicamente para serem respeitadas em seus modos de vida que resistem apesar da mineração desenfreada 
que marca toda a bacia do Rio Doce. Com esse trabalho artístico, buscamos compartilhar nossa vivência com um público maior e apresentar essa experiência a partir de mecanismos que extrapolem o texto, o artigo e o convencimento argumentativo. A ideia foi provocar, assim como nas arenas itinerantes, a criação de uma experiência singular no público, entendendo-a como o resultado de uma experiência que mobiliza os afetos. Ao virar a alavanca e sustentá-la, o espectador escolhe ouvir os atingidos e silenciar o trem.

\section{Nas Águas dos Manguezais de uma Reserva Extrativista, Histórias sobre Humanos e Caranguejos, Colaborações e Contaminações ${ }^{2}$}

Compartilharei aqui algumas reflexões sobre um projeto de pesquisa coletivo que coordeno, que está ainda em andamento, e farei alguns apontamentos sobre minha experiência de trabalho em uma de suas áreas de pesquisa, mencionando as formas como a equipe tem praticado modos de colaboração. O projeto em questão chama-se "Ecologia política da pesca de crustáceos em manguezais do Nordeste brasileiro", sediado na Fundação Joaquim Nabuco e realizado em colaboração com pesquisadores da Unilab, da UnB e do ICMBio.

Realizamos pesquisas de campo em cinco áreas de manguezais da região Nordeste, estuários em que a vida marinha interage com a vida fluvial e terrestre. São sítios caracterizados pelo fluxo das marés que gera intensa variação de salinidade e pela grande quantidade de matéria orgânica dissolvida na água trazida pelos rios. Os manguezais têm grande relevância para a reprodução de diversas espécies marinhas e são também habitados por animais e vegetais exclusivos desse tipo de ambiente, a exemplo de algumas espécies de caranguejos semiterrestres. De fato, a produtividade biológica atribuída aos manguezais permite que as comunidades pesqueiras dessas áreas obtenham uma variedade de pescados que dependem de diferentes maneiras de se engajar nos manguezais.

Perguntamo-nos, em nosso projeto, sobre quais histórias podemos contar em cada uma dessas paisagens, sobre como as formas específicas de existir dos caranguejos se articulam com os modos de existência dos pescadores em contextos de destruição, de contaminação e de precarização, mas também de efervescente produção de vida. E, muitas vezes, essas histórias nos contam sobre como o mangue faz política. Nesse panorama, manguezais podem ser vistos como paisagens de fricção em que não é possível compreender os fenômenos do capitalismo global senão a partir de suas conexões e manifestações locais, em que as forças capitalistas acontecem em interações baseadas na diferença, tanto como conflitos quanto como alianças, empréstimos, fusões, traduções e acomodações.

Capítulo elaborado por Pedro. 


\subsection{Os Habitantes da Paisagem da Pesca, da Contaminação e da Gestão}

Apresento aqui brevemente a paisagem da atividade de captura de caranguejos no estuário do Rio Goiana, na divisa de Pernambuco com a Paraíba. É uma área de manguezais circundada por uma matriz de cana-de-açúcar, cultivada historicamente em grandes propriedades desde os tempos coloniais, mas que teve uma expansão na segunda metade do século XX face ao Programa Nacional do Álcool (Proálcool). Nos últimos 30 anos, o lado pernambucano em torno do estuário passou a ser alvo de empreendimentos industriais incentivados pelo Governo do Estado, em adição às usinas de cana-de-açúcar. São infraestruturas para produção de camarão em cativeiro (carcinicultura), na década de 1990, e mais recentemente indústrias de cimento, tintas, vidros e automobilística (SILVEIRA et al., 2013).

Os pescadores artesanais do Rio Goiana vivem em povoações nos arredores dessa área de mangue, tanto do lado pernambucano do Rio quanto do lado paraibano. A pesca e o engajamento nas atividades no manguezal são reconhecidos na literatura sociológica como um espaço histórico de autonomia das coletividades litorâneas da região frente ao sistema da plantation (RAMALHO, 2008), em face de uma estrutura fundiária altamente concentrada caracterizada pela substituição da floresta pela cana. A pesca ("ir para a maré", como dizem os pescadores e pescadoras) é também uma fonte de segurança alimentar e financeira diante da instabilidade econômica e da situação de desemprego. Os empreendimentos industriais instalados na região não cumpriram a promessa de gerar muitos empregos para os moradores da região e, em contrapartida, causam diversos prejuízos aos manguezais e conflitos com os pescadores por causa da poluição, do desmatamento e do impedimento de acesso ao mangue e às áreas de pesca.

Figura 2 - Pescador de caranguejos em manguezal regenerado sobre tanque de peixes abandonado, Povoado de Carne de Vaca (Goiana, PE)

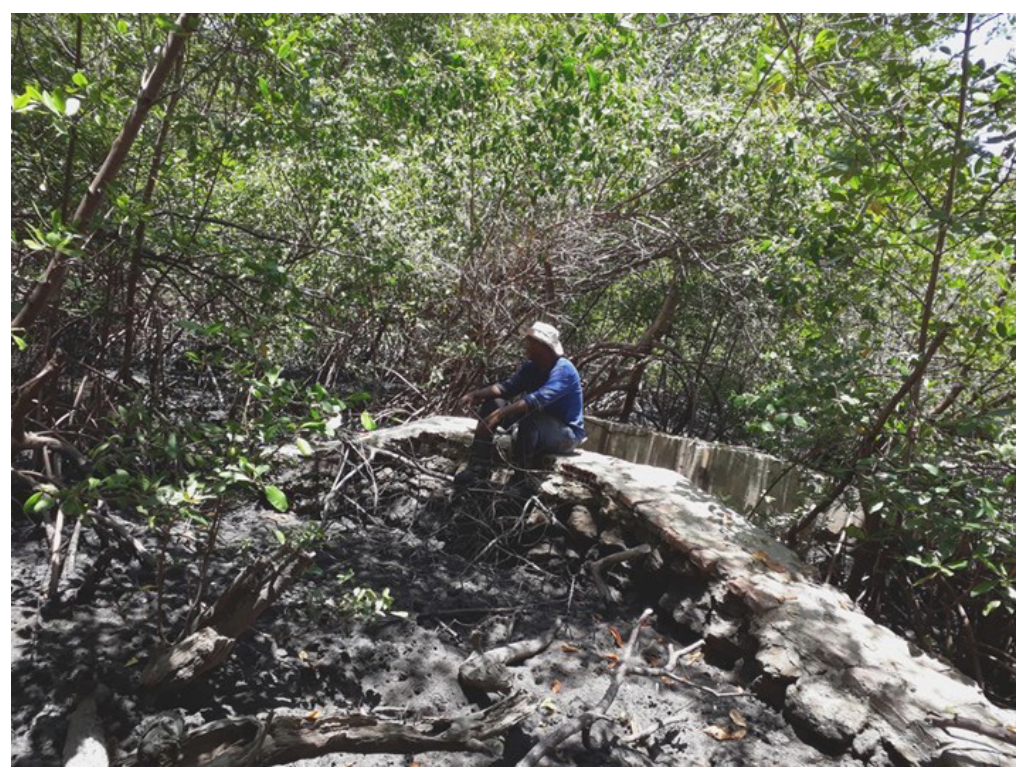

Fonte: Acervo de Pedro Silveira (2019) 
Em 2007, lideranças das comunidades pesqueiras, assessoradas pelo Conselho Pastoral dos Pescadores (CPP) e em colaboração com universidades e centros de pesquisa, bem como com o Ministério do Meio Ambiente, conseguiram que fosse criada, no estuário do Rio Goiana, a Reserva Extrativista (Resex) Acaú-Goiana, que tem seus limites coincidindo com os manguezais do Rio Goiana, acrescido de um trecho de área marinha (SILVEIRA et al., 2013; SILVEIRA; BUTI, 2020). Com a criação da Resex, as comunidades pesqueiras do estuário do Rio Goiana conquistaram o reconhecimento institucional do direito a sua prática histórica de utilizar os mangues para suas atividades de vida. Entretanto, os manguezais seguem sendo alvo frequente de despejo de esgoto domiciliar e industrial, episódios de mortalidade de animais por subprodutos da indústria de cana e da carcinicultura, desmatamento de áreas de mangue e de áreas limítrofes, eventos que contribuem para a contaminação e a simplificação da ecologia do ambiente, causando a precarização da vida dos habitantes humanos e não humanos do manguezal.

Os manguezais do Rio Goiana são habitados por três espécies de caranguejos semiterrestres que são alvo de captura tradicional por pescadores artesanais. O caranguejouçá (Ucides cordatus), o guaiamum (Cardisoma guanhumi) e o aratu (Goniopsis cruentata) têm diferentes modos de viver e compõem malhas de relações no manguezal que implicam diferentes ecologias políticas. A captura desses três tipos de caranguejo, na Resex AcaúGoiana, é feita por pescadores relativamente especializados e com o uso de técnicas e de apetrechos diferentes: redinha ou tapagem para o caranguejo-uçá, ratoeira para o guaiamum e vara e balde para o aratu. Suas pescarias também configuram controvérsias e conflitos diversos um do outro.

Os debates públicos sobre o caranguejo-uçá no Conselho Deliberativo da Resex AcaúGoiana durante a pesquisa transitaram, por um lado, pela discussão da revisão do marco regulatório nacional de sua captura em Brasília e pela regulamentação de sua captura dentro do acordo de gestão ${ }^{3}$ da Resex, o que envolve os debates a respeito das técnicas, dos tamanhos e do sexo dos caranguejos; e, por outro lado, debates a respeito da poluição das águas dos mangues pelas usinas de cana-de-açúcar e pelos empreendimentos de carcinicultura. Além disso, há um grande debate entre os pescadores e os gestores da conservação a respeito do período reprodutivo, a chamada andada. Há, ao mesmo tempo, um consenso entre os caranguejeiros e seus interlocutores sobre ser inadequado capturar caranguejos na andanda, e uma prática comum quase generalizada de captura nesse período. Uma das reivindicações dos pescadores era a da disponibilização pelo governo de algum tipo de apoio financeiro nos moldes dos seguros-defeso aos pescadores. A principal controvérsia a respeito do aratu nos debates da Resex relaciona-se às duas formas de captura que ocorrem: uma mais antiga, realizada de dia principalmente por mulheres, com uma vara; e outra, criada nos últimos anos, realizada à noite por homens, considerada nos debates do Conselho da Resex como mais predatória e vista pelos pescadores como injusta, pois captura os aratus em maior quantidade, quando estão repousando na copa das árvores de mangue. Por fim, o guaiamum teve sua captura proibida em todo o Brasil a partir de novembro de 2019 por ser considerado, nos termos legais, criticamente ameaçado. São grandes as controvérsias a esse respeito (SILVEIRA; BUTI, 2020), desde

O Acordo de Gestão é um documento produzido nas reservas extrativistas que apresenta as regras de uso pactuadas entre as comunidades da reserva e o poder público. 
as relacionadas ao nível da ameaça ao qual os guaiamuns estão sujeitos, até a respeito de se o fato de se proibir a atividade dos goiamunzeiros é uma medida eficiente para conservar os guaiamuns.

Lado a lado ao acompanhamento e à participação nas controvérsias a respeito da pesca dessas três espécies de caranguejos, acompanhamos pegadores de caranguejo, guaiamum e aratu, em suas atividades de trabalho, engajados em um manguezal multiespécies, a partir da perspectiva de pensar os caranguejos como espécies companheiras dos humanos (HARAWAY, 2003). O compartilhar de tais engajamentos foi fundamental para balizar nossa colaboração político-institucional em relação aos debates sobre pessoas e caranguejos na Resex. Assim, nossa perspectiva de colaboração formal como projeto de pesquisa é a de nos inserirmos nas redes locais de colaboração. Nossa colaboração com pescadores e gestores públicos tem como diretriz a continuidade das relações estudadas, em uma perspectiva do ter/tomar cuidado (STENGERS, 2015). Pontuaremos a seguir como esse engajamento acontece nesse caso específico, de maneira contextual, além de indicar como o cenário institucional e os eventos recentes se reproduzem neste caso. Ainda não temos como avaliar os desdobramentos futuros desta colaboração.

\subsection{Engajamento Colaborativo nas Malhas dos Mangues}

A colaboração, no projeto de pesquisa, tem se dado de maneira heterogênea, a partir das especificidades de cada paisagem e de como os pesquisadores se inserem nela. É assim que os resultados e os processos das pesquisas têm se colocado até agora em uma arena pública de debates. É dessa forma que pretendemos pensar os desdobramentos das pesquisas. A ideia é que estejamos falando com e ao lado das organizações dos pescadores com quem interagimos e privilegiando um ponto de vista de dentro dos manguezais, ao invés de falar em nome dos pescadores, dos caranguejos ou dos manguezais. Isso, é claro, compreendendo as dissonâncias possíveis nas controvérsias entre os próprios pescadores e considerando a autonomia dos pescadores em assumir ou não posições marcadas nos conflitos.

No caso da Resex, existe um histórico de colaboração de um grupo de pesquisadores da Fundação Joaquim Nabuco com organizações dos pescadores e organizações assessoras, anterior a este projeto de pesquisa, que inclui nossa participação em atividades dos pescadores e participação nas institucionalidades. O Conselho constitui um ambiente heterogêneo de colaboração e de conflito, cujo funcionamento depende muito da postura dos gestores do ICMBio que passam pela administração e do grau de mobilização dos pescadores e dos outros participantes, bem como do contexto mais ou menos favorável das políticas e dos recursos vindos de Brasília.

Durante a realização de nosso projeto, uma das formas de colaboração que produzimos foi a participação na Câmara Técnica dos crustáceos, que era um espaço formal do Conselho criado a partir da emergência da controvérsia sobre o guaiamum, mas também sobre as questões do aratu e do caranguejo face ao acordo de gestão, que havia sido produzido anos antes, e demorou anos para ser aprovado e, quando foi aprovado, precisava ser reapresentado aos pescadores para possíveis revisões. A Câmara Técnica foi um espaço 
que conectou ações de técnicos do governo, pesquisadores de diferentes instituições, representantes dos pescadores e caranguejeiros do Conselho Pastoral dos Pescadores, em algumas ações conjuntas.

A participação dos pesquisadores do projeto nessas instâncias, lado a lado com as experiências de estar no mangue com os pescadores, abriu também a possibilidade de compreender demandas de pesquisas que interessavam aos pescadores a respeito da pesca e da vida dos caranguejos, que pretendemos que sejam desenvolvidas em um futuro próximo, assim como demandas por ações de valorização pública, como ações nas escolas e produção conjunta de materiais didáticos. Como dissemos, a expertise para perceber as possibilidades de colaboração vem a partir do engajamento no mangue e na pesquisa de campo.

As transformações políticas que ocorreram no Brasil após a eleição de 2018 afetaram diretamente os processos colaborativos em andamento, dos quais nosso projeto faz parte. Para citar alguns exemplos, o Conselho Deliberativo da Resex Acaú-Goiana foi desmobilizado com a ausência das reuniões ordinárias trimestrais previstas. Houve ainda redução do quadro de servidores na Resex. Tudo isso acabou por desmobilizar também a Câmara Técnica dos Crustáceos, sem contar o processo de afrouxamento da regulação ambiental estatal. Além disso, tivemos uma crise no processo de financiamento e de gestão de pesquisas científicas e de enfraquecimento da atuação do setor público de forma generalizada, o que afetou nossas instituições de origem e tornou mais difícil estarmos em campo com nossos interlocutores e propormos desdobramentos de nossos trabalhos. E ainda, os pescadores artesanais tiveram seus direitos sociais abalados pela não renovação dos Registros Gerais de Pescadores, extinção do Ministério da Pesca e pela reforma da Previdência Social.

Os processos de colaboração estabelecidos durante nosso projeto de pesquisa terão continuidade. A pesca artesanal persiste há séculos no litoral nordestino, provendo devires de autonomia e de segurança alimentar aos pescadores, em um modo de existência que pressupõe a continuidade da existência dos caranguejos e outros seres que compõem e habitam a paisagem do manguezal. Esses pescadores e caranguejos nos inspiram a seguir em frente apesar dos ambientes e dos modos de existir precarizados.

\section{Na Bahia de Todas as Águas: um recado do mangue nas margens do petróleo ${ }^{4}$}

Apresento as experiências e engajamentos criativos que vêm posicionando o manguezal para dentro das preocupações de pesquisa, ensino e extensão na universidade em que atuo, a Unilab, no município de São Francisco do Conde. Essa cidade localizase no Recôncavo da Bahia e possui sua linha litorânea em boa parte contornada pelo ecossistema manguezal. O que implica dizer que boa parte dos estudantes moradores da cidade pertence a famílias que fazem da pesca uma prática de geração de renda e segurança alimentar, além de estabelecer, com esse mesmo ecossistema, vínculos de relação histórica e afetiva.

Capítulo elaborado por Rafael. 
Além disso, a cidade tem lugar especial na história da cadeia canavieira e petroleira nacional, o que faz as paisagens de mangue serem conformadas pelo que Anna Tsing (2019) tem chamado de infraestruturas imperiais e industriais do Antropoceno. Ali nasceu tanto o Brasil colonial escravista dos grandes latifúndios e engenhos de cana-de-açúcar quanto o Brasil petroleiro dos anos de 1950, marcando a ruptura do sistema da agroindústria açucareira para o sistema das indústrias petroquímicas que ali se instalaram, transformando radicalmente as paisagens de manguezal da Baía de Todos os Santos (PINTO, 1998).

Por isso a cidade conjuga aos territórios pesqueiros no manguezal o arruinamento dos ambientes de pesca, a concentração fundiária e a frouxidão da legislação ambiental para o latifúndio e a petroquímica, tensionando o modo de vida dos pescadores artesanais a duas forças: a grande propriedade, que cerceia a liberdade de habitar o mangue e devasta territórios com o agronegócio, o hidronegócio e a pecuária; e o complexo petroquímico e seus modos de perturbação e contaminação, desde as bases ativadas e desativadas de exploração do petróleo até o sistema de escoamento, refino e transformação, os aterros sobre o mangue e as áreas devastadas pelos constantes vazamentos. Por isso, falar da história de São Francisco do Conde, é falar da história do petróleo e do monocultivo no Brasil e suas inscrições nos territórios habitados por comunidades negras.

Elucidar esses aspectos do contexto é importante para introduzir o porquê e como estão sendo realizadas algumas atividades que colocam o manguezal para dentro das práticas da Unilab, pensadas como experiências coproduzidas junto às comunidades quilombolas e pesqueiras. A inspiração para o desenvolvimento das propostas guiou-se por alguns engajamentos comunitários na produção de dinâmicas que podem ser entendidas como ecopedagógicas (GADOTTI, 2001, p. 89). Nelas, comunidades têm produzido vivências sobre aspectos de sua vida e história a partir de um roteiro de navegação nos ambientes, relegando ao que chamamos de "natureza" um importante lugar de referencialidade da "cultura". Essas dinâmicas têm dimensão socioambiental e se dão como forma de valorizar o coletivo, reforçar direitos territoriais, fomentar a economia local e denunciar problemas vividos.

Nessa mesma abordagem ecopedagógica trarei alguns exemplos de atividades de ensino, pesquisa e extensão realizadas com comunidades quilombolas na Grande Salvador, capital do estado situado a 60 quilômetros da Unilab.

\subsection{Ecopedagogias Quilombolas como Modo de Contar a História no Chão}

Uma delas foi um curso de extensão oferecido em 2017, chamado Diálogo de Saberes com Quilombos. A intenção foi introduzir o debate sobre quilombos conjugando alguns encontros em sala de aula (guiados por referências bibliográficas) com as dinâmicas guiadas pelas comunidades de Cordoaria e Dom João. A ideia não era somente fomentar a discussão para os estudantes e fazê-los conhecer territorialidades quilombolas, mas propiciar intercâmbios entre os participantes nos seus lugares de vida e produzir o compartilhamento de experiências. 
A conexão com Dom João se deu por estar localizada em uma área de manguezal e ter como uma de suas lideranças a dona Joselita Gonçalves, matriculada no curso de Bacharelado em Humanidades da Unilab. Desde meu ingresso na Unilab, realizo pesquisa em Dom João, com foco nos modos de habitar em relação aos efeitos da cadeia petroleira e das pressões impostas pelos fazendeiros e pelo poder público local (BUTI, 2019; SILVEIRA; BUTI, 2020). Já Cordoaria compôs o curso por desenvolver atividades ecopedagógicas, como as Trilhas Étnicas Ecológicas de Cordoaria oferecidas ao público externo, sobretudo estudantes da rede pública de Camaçari ${ }^{5}$. O fato de a comunidade estar em um município fora do Recôncavo foi um modo de conectar áreas de manguezal com outros contextos e ecossistemas, reforçando a novidade das experiências.

Inspirados nas Trilhas Étnicas Ecológicas, construímos um plano de curso que intercalava a cada encontro em sala de aula um encontro nos territórios de Cordoaria e de Dom João, totalizando quatro encontros. Neles, pudemos construir narrativas da vida e história da comunidade referenciadas nos ambientes. A produção da narrativa ficou ao encargo da comunidade, que guiou os participantes ao longo dos lugares/histórias. Assim Cordoaria, por exemplo, celebrou a reativação de seu engenho de farinha conduzindo os participantes pela mata que dá acesso ao Rio Joanes, cujas águas, represadas nos anos de 1930, submergiram um engenho senhorial antigo e as casas dos ancestrais escravizados, cujos descendentes foram obrigados a deslocar-se abruptamente. A narrativa ligava a mata e o tacho de farinha "dos tempos dos escravizados" incrustrado na beira do rio a um mestre de ofício agricultor que contou, de dentro do engenho, a história da comunidade a partir da mandioca, enquanto o beiju era produzido por algumas anciãs.

Em Dom João fomos conduzidos às áreas de manguezal e aos aterros da Petrobrás sobrepostos ao mangue. Guiados por um gaiamunzeiro e uma marisqueira de barco a motor pelo rio Dom João e pelos caminhos alagadiços do manguezal, os caminhantes acompanharam a captura de sururus e guaiamuns, além de conhecer os efeitos do racismo ambiental nos lugares em decorrência das estruturas em ruínas do petróleo vistas no chão. Inspirados em Cordoaria, os moradores de Dom João nos conduziram a um senhor agricultor que nos apresentou algumas variedades de mandioca, das quais informou dar, "de agrado", ao senhor da fazenda, uma vez que não tem terras para plantar. Essa experiência mostrou as assimetrias na relação do agricultor quilombola com os proprietários de terra no Recôncavo, que condicionam a possibilidade de produzir mandioca à obrigação de uma retribuição abrandada pelo "agrado", conotativo das assimetrias do meio rural brasileiro (MOURA, 1991).

Ambas as vivências tiveram um comum desfecho: pratos típicos foram oferecidos aos participantes ao som de músicas locais, com intuito de fortalecer o comércio familiar, celebrar a vida, os saberes e o trabalho vinculados à pesca, à culinária e à agricultura. O compartilhamento do alimento é uma forma de ritualizar a força da vida e da comunhão diante da morte e da violência, impostas pelos inimigos históricos: o racismo, a escravidão, o fazendeiro, a invisibilidade na História e na oficialidade, a contaminação e o arruinamento das paisagens estuarinas. O compartilhamento é uma forma de mostrar que no prato e na panela está tudo o que vimos durante o trajeto, na terra e das águas do que é plantado,

Essa informação pode ser consultada em: https://quilombocordoaria.wixsite.com/cordoaria. 
colhido e pescado pelas mãos de quem ali vive. Em suma, é uma forma de mostrar a dimensão do cotidiano, sua alegria e força, como um modo de resistência que se deve preservar e valorizar.

\section{2 “Caminhaulas" como Educação no Ambiente}

Figura 3 - Diálogo de Saberes, Quilombo Dom João

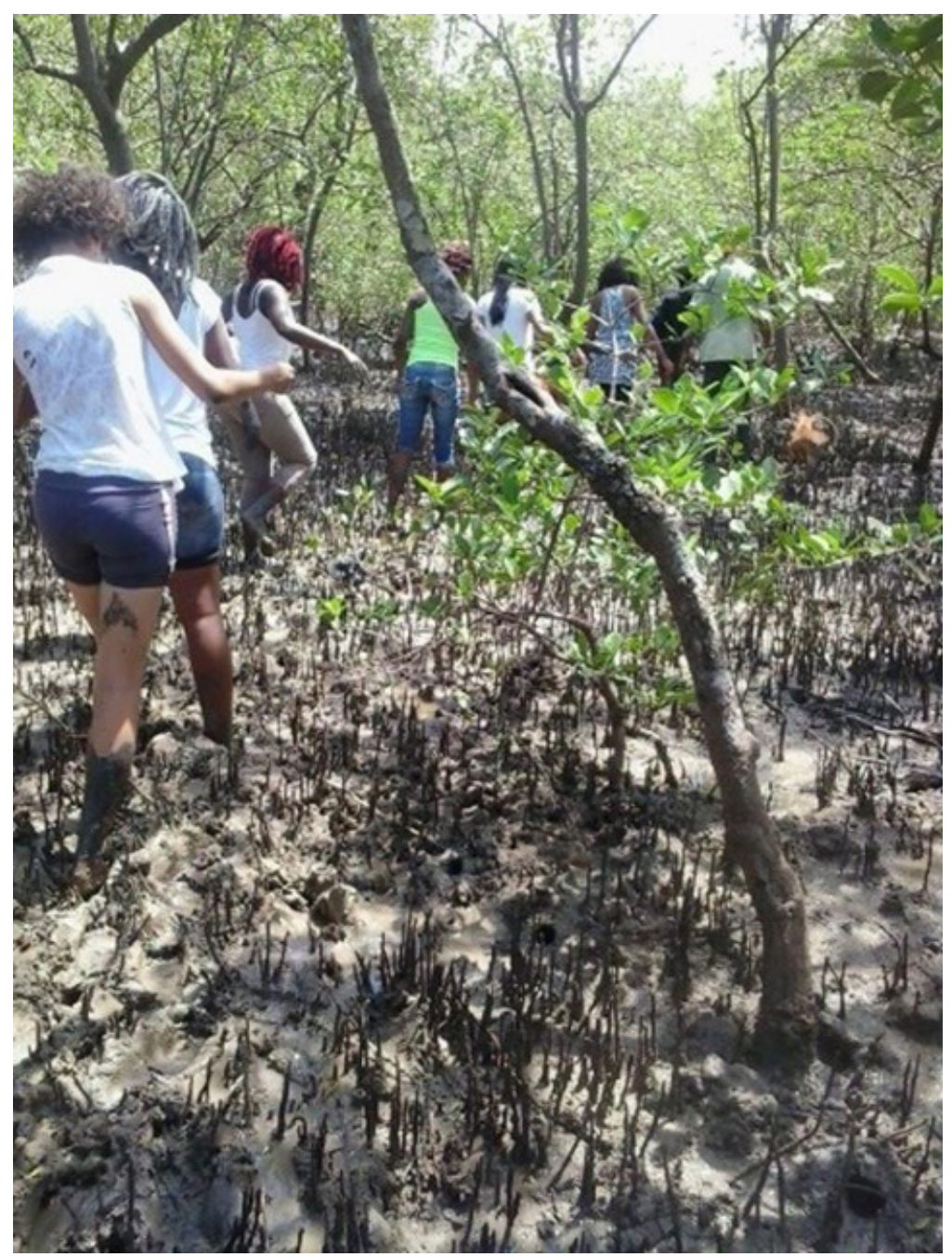

Fonte: Acervo de Rafael Buti (2017)

Engajamentos comunitários que pretendem comunicar o local ao externo e as dinâmicas ecopedagógicas parecem jogar com duas dimensões importantes enfatizadas pelo antropólogo Tim Ingold (2015): a primeira é a de que as histórias estão imersas no mundo e que devemos devotar às paisagens um lugar importante na compreensão do social; e, a segunda, é a de que caminhadas são recursos metodológicos da pesquisa, estas, pensadas como experiências de acesso e compartilhamento das perspectivas locais. Além das dimensões epistemológica e metodológica, as propostas trazem uma dimensão pedagógica, uma vez que pretendem, sobretudo, ensinar. 
Inspirado nas experiências de Dom João e Cordoaria, passei a incorporar as caminhadas dentro do componente Cultura e Meio Ambiente, Território e Identidade e Laboratório de Saberes da Unilab como instrumento de compartilhamento de saberes articulado aos textos. Batizadas por uma das estudantes de caminhaulas, essas dinâmicas foram coproduzidas com os habitantes dos lugares, incluindo os próprios estudantes. As caminhaulas potencializaram a compreensão dos temas, produzindo sensibilização multissensorial e retorno muito positivo por parte dos discentes.

A dimensão ecopedagógica nas aulas tende a tensionar nosso lugar comum como docentes acadêmicos, quando reservamos aos limites da sala de aula e dos livros a exclusividade da referencialidade dos saberes. Tensiona, também, o controle que exercemos na condução da turma. Caminhaulas nos fazem perder (metafórica ou literalmente) o chão, o privilégio do controle da situação, e também deixa que os próprios acontecimentos gerados em movimento produzam reflexões, histórias, conexões e experiências não previstas, que se tornam fundamentais para o processo reflexivo.

Como exemplo, cito nossa caminhada para ver o vazando de um duto da Petrobrás em cima do mangue no território quilombola de Dom João, como forma de entender as perturbações invisíveis de longa duração e seus efeitos devastadores nas paisagens e nos modos de habitar o manguezal. Ou os pássaros-pretos que anunciam que se pode colher dendê e, assim, alimentar os guaiamuns capturados. Ou uma planta que é encontrada e logo remetida às diferentes memórias dos muitos lugares de onde vieram os estudantes, no Brasil e na África, gerando conectividade em seus modos de pensar e de saber a despeito das múltiplas trajetórias. Ou o cheiro dos gases que se percebe ao nos aproximarmos de uma base de refino da Petrobrás. Ou o silêncio que se nota ao percorrer um manguezal morto.

\subsection{Tóxico Tour Dom João}

Por fim, outra atividade importante de colaboração em tempos de catástrofe foi o Tóxico Tour Dom João, realizado em pareceria com a associação quilombola Dom João. Essa atividade se inspirou no Tóxico-Tour Ilha de Maré, comunidade quilombola localizada em uma das ilhas da porção sudeste da Baía de Todos os Santos. Nessa comunidade, o TóxicoTour vem sendo realizado junto ao Movimento dos Pescadores e Pescadores Artesanais da Bahia e tem inspiração nas dinâmicas da campanha antipetroleira Nenhum Poço a Mais $^{6}$. Trata-se de um tour feito em pequenas embarcações mediado pelas lideranças comunitárias, cujo desfecho é aportar na ilha, conhecer alguns lugares e compartilhar a culinária e a musicalidade locais.

Navega-se embarcado e embalado em lugares/histórias das águas, tendo como referentes tanto coroas perturbadas por dragas, poços de petróleo em áreas de mangue, colorações das águas indicando canos subterrâneos, grandes navios que levam e trazem as commodities (minérios, petróleo) saindo e chegando do complexo industrial de Camaçari e do polo naval de Aratu, esse corredor logístico do geocapitalismo global que se tornou a Baía de Todos os Santos.

\footnotetext{
6 Para mais informações sobre esse assunto, consultar https://areaslivresdepetroleo.org/.
} 
Inspirados na proposta de navegar pela toxidade e de produzir um desfecho de comensalidade e de vida comunitária, engajamos junto a Dom João um tour pelos lugares contaminados por um vazamento de petróleo ocorrido em maio de 2018. Os participantes puderam conhecer os efeitos imediatos (visuais, sonoros, táteis, olfativos) de um vazamento ao percorrerem todo o petróleo e os rastros de destruição deixados. A atividade serviu, também, para solicitar à Defesa Civil do município (lugar também visitado pelo trajeto) medidas de reparação aos danos causados.

As dinâmicas ecopedagógicas na Unilab revelam, sobretudo, os efeitos da democratização da universidade pública no Brasil e a reverberação da diversidade de saberes nas práticas de pesquisa, ensino e extensão. A antropologia, embora pretenda uma sinergia conceitual com outros saberes, não assumiu a necessidade de incorporar essa diversidade no ensino, crítica já formulada por antropólogos indígenas como Gersem Baniwa (2008). Em suma, precisamos colaborar para nossa "virada", também "pedagógica", atentos para o princípio de uma coprodução que reverbera no modo de estabelecer experiências para o compartilhamento dos saberes/lugares/histórias. É preciso estar, também, atento aos limites éticos de se trabalhar em contextos de contaminação, uma vez que as comunidades podem ficar expostas ao estigma. A ação deve ser sempre coproduzida, e a ênfase deve ser a vida e a busca pelos direitos.

\section{Nas Águas do Idixidi, Mapa da Vida Munduruku nas Lutas Contra-Antropocênicas Diante do Impacto dos Projetos Hidrelétricos aos "Lugares Sagrados"7}

Contarei uma história sobre engajamentos colaborativo em um processo de mapeamento do território Sawre Muybu, situado no Idixidi (o Rio Tapajós), ocorrido entre 2016 e 2018, e que foi denominado de Mapa da Vida Munduruku ${ }^{8}$ Tratarei de descrever processos de produção cartográfica considerando as convergências, as divergências e os equívocos de uma pesquisa colaborativa por entre diferentes regimes de conhecimento ecogeográficos, voltados para a compreensão da cosmografia do mundo indígena diante da iminente catástrofe frente à construção de hidrelétricas no Idixidi. O desafio do Mapa da Vida foi o de conseguir traduzir em uma base bidimensional/audiovisual a perspectiva Munduruku sobre o mundo e, ao mesmo tempo, realizar a tradução de conceitos que emergem no mundo vivido em categorias legíveis para um público amplo, dos moradores das periferias das grandes capitais, passando pela mídia e o ministério da justiça.

Formulado pelas lideranças do povo indígena Munduruku do movimento Ipereg Agu junto com apoiadores, como o Greenpeace Brasil, a confecção do Mapa da Vida se deu no contexto de automobilização para a produção cuidadosa de mapas voltados para a visualização de suas perspectivas sobre os lugares habitados por humanos e não humanos. O mapeamento, como um exercício cosmopolítico de tradução por entre a diferença pretendia ser um "instrumento a mais" para "falar ao mundo" sobre as ameaças de arruinamento dos lugares habitados pelas miríades de vida que compõem o cosmo.

\footnotetext{
Capítulo elaborado por Thiago.

8 Para mais informações sobre este assunto, consultar: https://br.heartoftheamazon.org/omapadavida/
} 
Como mesmo afirmou Ana Poxo9: "O mapeamento é para fortalecer nossa luta e para mostrar onde estão os lugares que não podem ser destruídos, onde estão nossas coisas sagradas, tudo que não pode ser tocado".

Esse "instrumento a mais", o Mapa da Vida, foi proposto após um exercício de negociação permanente entre as lideranças Munduruku e destes com instituições não governamentais que atuavam em torno da luta contra a construção de hidrelétricas na Amazônia. Essa negociação se deu após dois eventos importantes ocorridos em 2016, vistos como vitórias dos Munduruku: o não aceite e o arquivamento do Estudo de Impacto Ambiental (EIA) da Usina São Luiz do Tapajós por parte do O Instituto Brasileiro do Meio Ambiente e dos Recursos Naturais Renováveis (IBAMA) e a tão aguardada assinatura e publicação da portaria de identificação e delimitação da Terra Indígena Sawre Muybu, reconhecendo-a como terra tradicionalmente ocupada. Devemos lembrar que tais conquistas se deram após anos de mobilização e táticas de resistência cotidiana.

Porém, mesmo diante dessa "vitória" parcial representada pelo arquivamento do licenciamento da usina e identificação da Terra Indígena, o território de Sawre Muybu ainda não tinha sido definitivamente demarcada, e o governo federal e os empreendedores não haviam cancelado em absoluto os mais de 40 projetos hidrelétricos para a bacia do Tapajós, muito pelo contrário, os Munduruku ainda estavam mobilizados contra a destruição de um local sagrado chamado de Karobixexe pelas obras da Usina de São Manoel, no Rio Teles Pires, afluente do Tapajós. Diante dessa permanente ameaça, os Munduruku começaram a atuar para inverter a narrativa: do Tapajós como "vazio demográfico" e "recurso hídrico" como promovia o governo federal da época e seus apoiadores na mídia corporativa, para o Idixidi como morada dos peixes e dos espíritos protetores, como território indígena. Ao mesmo tempo, o instrumento "mapa" poderia contribuir com o fortalecimento das ações de defesa de seu do direito originário em viver em um ambiente que lhes permita a reprodução física e cultural e pressionar o Estado brasileiro que se recusava a realizar a demarcação de Sawre Muybu, justamente porque tal demarcação impediria a construção de São Luiz do Tapajós.

\subsection{Projetos Hidrelétricos, Povos Indígenas e suas Equivocações}

A projeção da construção de hidrelétricas no Tapajós se deu nos anos de 1970, durante o regime Militar, mas não se concretizou. Nos anos 2000, o projeto voltou com força apoiado pelo Governo Federal via o consórcio NorteEnergia, criando o Complexo Tapajós. Mais de 40 hidrelétricas estão previstas ou em construção na região, também ameaçada por planos de construção de uma hidrovia para escoar a produção de soja do Mato Grosso para o Oceano Atlântico.

Na linguagem da governança, o Rio Tapajós é um vazio demográfico e lócus da não vida (deserto) (POVINELLI, 2016), suas águas são vistas como recursos, medidas em KW e em moeda. Tal formulação está explícita no Estudo de Impacto Ambiental da obra, em que as águas, as cachoeiras e as rochas adentram em um capítulo de caracterização abiótica (GEO), que se separa dos seres vivos estudados (BIO) e em outra separação,

9 Informação obtida em depoimento durante o mapeamento. 
dos humanos (ANTROPOS), conformando uma geontologia que divide o mundo em vivos e não vivos e, depois, em natureza e cultura. Água como potencial hidrelétrico, exploração e expansão. Por meio dessa premissa ontológica, a NorteEnergia previa, após os estudos ambientais, iniciar as obras, o que envolveria dinamitar as rochas das cachoeiras, desmatar, bloquear o Rio Tapajós e alagar a floresta. Tudo o que os Munduruku, povo habitante histórico do Tapajós e atores da história que conto a vocês, se contrapunham em sua luta contra-antropocênica.

Na geontologia Munduruku tudo que existe é vivo, age no mundo e se constitui em relação, e tudo que é vivo é cuidado por alguém, um dono, um mestre cuidador. Tudo que é vivo um dia foi humano no tempo mítico, e, após processos transformativos, se transforma em diversas formas atuais, com almas humanas e corpos diferenciados (diversos tipos de peixes, animais, árvores, etc.), conformando uma ontologia em que o dualismo natureza e cultura não faz sentido. Rochas são vivas, assim como a água. Rochas e águas conformam as moradas dos seres extra-humanos, são lugares sagrados que abrigam os outros, os peixes e suas mães, espíritos poderosos com os quais os Munduruku devem negociar, via xamanismo, o acesso às águas. Portanto, para os Munduruku, não há nada nas águas e nem nas matas que nos faça pensar que seja tudo um grande palco vazio, inabitado e inerte. Muito pelo contrário, o mundo é polvilhado de moradas, onde vivem os diversos seres e seus cuidadores em constante movimento. É com esses donos das moradas que os Munduruku negociam constantemente o acesso às águas e às florestas - ao mesmo tempo em que estabelecem comunicação no mundo onírico ou xamânico. O rompimento dessas relações, que se daria pela explosão e alagamento das moradas dos peixes e das mães dos peixes pela construção das barragens, bem como pela destruição de suas moradas pela mineração, é percebido como um evento catastrófico, ou até cataclísmico que deve ser evitado. A consequência seria o fim do mundo como existe, o dilaceramento das coordenações entre as vidas que mantêm a habitabilidade na paisagem.

Os Munduruku vêm empreendendo uma guerra contra as barragens, argumentando que o Idixidi é tudo menos um rio vazio e que as hidrelétricas vão destruir seus lugares sagrados e seu modo de vida de forma irremediável. O governo de ocasião desconsiderava completamente essa perspectiva indígena e, para implementar o projeto, militarizou a região e não consultou os Munduruku. Estava instalada a incomensurabilidade entre modos de existência, em uma guerra geontológica estabelecendo cenas do geontopoder, no sentido de Polvinelli (2016), no Rio Tapajós.

\subsection{Mostrando a Paisagem Ativa: o mapa da vida Munduruku}

O mapeamento teve início em junho de 2016 na aldeia Sawre Muybu. Participaram todas as lideranças dos territórios Munduruku do Médio Tapajós e alguns convidados do território do Alto Tapajós, bem como os habitantes de todas as aldeias da Terra Indígena. Junto aos principais personagens ali presentes que personificavam o conhecimento Munduruku, havia dois pajés, que, além de contribuírem com a produção do mapa, estavam de prontidão para indicar e controlar o que poderia ser dito ou não dito e 
apontar o acesso aos locais habitados por não humanos e extra-humanos que poderiam ser visitados ou não durante as caminhadas no mapeamento. Um coletivo de jovens cineastas Munduruku registrava as narrativas e as atividades realizadas em formato audiovisual. Meu papel, como assessor do mapeamento junto com uma colega geógrafa, era o de proporcionar um leque de ferramentas da cartografia socioparticipativa e uma estratégia de tradução para dar conta de registrar e de evidenciar as concepções e as memórias de lugares sobre os modos de habitar o mundo pelos Munduruku ${ }^{10}$.

Figura 4 - Mapa da Vida Munduruku, Aldeia Sawre Muybu

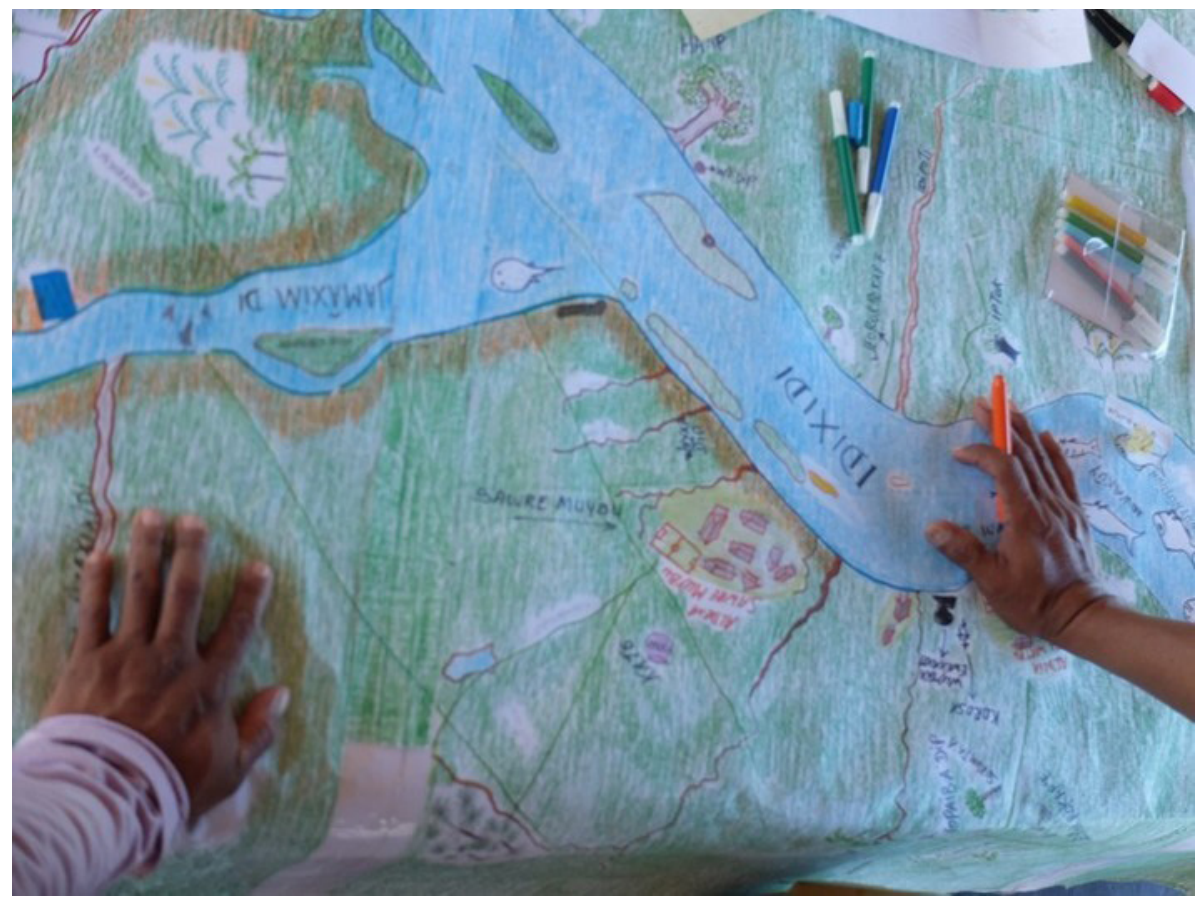

Fonte: Acervo de Thiago Cardoso (2017)

Muitas pessoas colaboraram, durante os cerca de dois meses de oficina de mapeamento, com os processos de decisão e de confecção do mapa. Em um primeiro plano, a colaboração se deu entre as diversas lideranças Munduruku, homens e mulheres, de várias aldeias e os assessores. Neste momento, conversações foram estabelecidas com vistas a definir o protocolo comum do mapeamento, o roteiro/cronograma, os modos e os limites da tradução, os diferentes papéis e os potenciais usos do mapa como ferramenta política. Em segundo plano, se dava a colaboração entre os Munduruku que, por meio de lideranças, como Juarez Saw, Thiago Iko, Brasilino Saw, Jairo Saw, Solano Akai, Bruno Kaba, Ademir Kaba, Ana Poxo, Valto Dace, Alessandra Korap e o cacique geral Arnaldo Kaba, realizavam as mobilizações entre as aldeias e as articulações internas, apaziguavam conflitos, direcionavam as atividades, indicavam os jovens que fariam os desenhos, coordenavam a logística, definiam os lugares que seriam visitados para registro em vídeo das narrativas e delimitavam as histórias a serem contadas. Eram os pajés os

\footnotetext{
${ }_{10}$ Ressalta-se que, entre 2007 e 2015, contribui com a formulação do Projeto Político-Pedagógico e como professor de Agroecologia do projeto IBAOREBU - Ensino Médio e Profissionalizante Munduruku, coordenado pela FUNAI. Para a assessoria no Mapa da Vida, fui contratado pelo Greenpeace Brasil sob aprovação das lideranças.
} 
que se engajavam em garantir que as relações colaborativas com os seres extra-humanos fossem apaziguadas durante o mapeamento.

O mapeamento consistia em se desenhar histórias, tornando a paisagem ativa/viva. Situados todos na casa coletiva localizada no centro da aldeia Sawre Muybu, jovens e lideranças sentados no chão desenhavam os contornos que davam forma e cores ao mapa. Cada história contada da mitopoética e da geografia vivida Munduruku se entrelaçava com as mãos hábeis no desenho de linhas, topônimos e formas que indicavam a existência e os movimentos dos seres que habitam a malha de lugares. O lugar denominado Daje Kapap, a travessia dos porcos, uma forquilha que pressiona o leito do Idixidi, é criação de demiurgos como Karosakaybo que durante a fuga de seu filho o criou, ali indicando o momento em que as águas do rio surgem dos caroços do coco da palmeira tucumã. Cachoeiras e montanhas foram sendo criadas por Karosakaybo e passam a ser moradas dos peixes e animais após suas transformações, como Puca Ka'a, a montanha morada dos animais, lugares que não podem ser mexidos, são inalienáveis.

Durante a cartoprática, as cachoeiras e lagos (boiadores de Tracajá) iam sendo delineadas no mapa, expressando-se como moradas das mães dos peixes, lócus dos movimentos dos peixes que na migração para o Alto Tapajós e para os igarapés vão fazendo suas festas em momentos de alegria (icokcok ap - estado em que o peixe se encontra). Seguindo o mapa observamos o igapó que seria alagado, impactando jauarizais, castanhais, ilhas e os locais de pesca do ritual da tinguejada (wedip), são locais em que os Munduruku pescam os peixes depois que passam e vão para o pusuru duk (morada), onde ficam o verão todinho até o mês de dezembro, depois vão descendo no período da piracema. No mapa, os diversos animais de caça se movimentam na terra (ipi, terra firme em suas variações) por entre awaidip ( = natureza, floresta, mapa, em um sentido próximo de Urihi-Floresta dos yanomami), seus territórios, cuidados por suas mães da caça/animais, visitando florestas oligárquicas de kosudip, kopaibadip, ha'ip, woyxádip e cojoda. As marcas dos ancestrais se fazem visíveis na katôdip, locais antigos de terra preta e nas roças e capoeiras dos antigos moradores, onde agora se encontram as aldeias atuais (agok; anhunká, como lugar com cuidador) e suas casas ( $u k^{\prime} a$, envoltório completo, cuidado; sua variação complementar $k a^{\prime} a$ - roça).

A malha de lugares multiespécie, denominados de "sagrado", conforma uma teia de moradas dos seres extra-humanos e seus objetos (Ibiobuk = como imagem, foto, no sentido de seres que fazem parte da história do lugar, por exemplo, os rastros do povo queixada e suas imagens que ficam). É nos lugares que estão as imagens das gentes Munduruku (buyxim - subentende como humanos ou substantivo wuyjeyu gente verdadeira, ou os primeiros; os outros são deyuat ou pariwat - não são pessoas do grupo). Os pariwat (inimigos, brancos), ao destruírem as cachoeiras, matas e montanhas, estariam matando as imagens das pessoas e, ao mesmo tempo, destruindo (ium, sentido de acabar; jepaum, sentido de desaparecer, sumir) objetos sagrados inalienáveis (acabar/ quebrar/objetos palpáveis no sentido de coisas = ikakam), desestabilizando os mundos Munduruku e seus modos de vida. Mapear os lugares na luta contra as barragens é uma forma de manter as matas sempre bonitas e cuidadas (xipanikug), mantidas completas como devem ser (tip tim) e de ter "direitos" (a'oca but, quem pode somos nós), o que os 
pariwat não conseguem ver/perceber (itabi daw - perdido, não entende), pois não conhece a história das vidas no Idixidi.

\subsection{Mapa como Colaboração}

Entendemos colaboração como o trabalho conjunto por meio da diferença, e aqui estamos tratando de diferença entre regimes de conhecimento que conformam uma constelação de práticas cartográficas (CARDOSO, 2014). Essa diferença, no mapeamento colaborativo, não deve ser vista como as unidades culturais radicalmente distintas, mas como os diferentes modos de fazer relação na colaboração e na forma de se contar histórias, em um complexo jogo de traduções que se materializa na ontogenia do mapa. Portanto, durante os processos de mapeamento, as partes que adentram na malha colaborativa (lideranças, intelectuais indígenas, pajés, assessores, antropólogo, peixes, animais, seres extra-humanos) não colaboram com conceitos preestabelecidos em suas lógicas subjacentes, mas são contribuintes na produção de conceitos e palavras que vão ganhando sentido nas relações de aliança e sendo tecidas nesse processo cartoprático. Tradução e equívocos aqui se dão nas práticas e nos conceitos que adentram nessa malha relacional e se abrem para transformações (TSING, 2019).

Nesse sentido, um mapa, como o Mapa da Vida, poderia ser entendido não como uma totalidade, ou como representação de uma cosmografia particular (mapa cultural) que se contrapõe a uma cosmografia ocidental, mas como propriedade emergente de conexões parciais colaborativas entre os participantes que negociaram a emergência de sua forma, definiram as múltiplas perspectivas de suas histórias incrustadas e elaboraram táticas para direcioná-los em suas pluriversões nas contingências e indeterminações das malhas cosmopolíticas. Desenhos que, feitos por muitas mãos, fazem ver, existir, traduzir/transformar histórias em linhas, imagens e legendas, em que um termo (como a água e o peixe) é a figura e não sua representação, e a fala é um ato comunicativo/ performativo que faz as coisas acontecerem e aparecerem na superfície bidimensional do papel. A produção do Mapa da Vida nos ensinou que o ato colaborativo de mapear se faz como um processo no qual as vidas envolvidas se engajam perceptiva, performativa e dinamicamente no mundo, habitando-o em um emaranhando de relações, de onde partem narrativas, histórias e fluxos de poder.

\section{6 Águas Turvas, Antropologia Artesanal mais que Humana e o Saber-Fazer Artístico como um Método de Deslocamento do Olhar $^{11}$}

Buscar técnicas artísticas como a impressão botânica (ecoprint) para compor pesquisas acadêmicas colaborativas é uma forma de fazer com que atividades manuais tragam à tona convergências entre diferentes mundos, pesquisas, ambientes, meios, materiais, plantas, animais, fungos e humanos. Dar voz às plantas faz com que as paisagens narradas

${ }^{11}$ Capítulo elaborado por Natália. 
por meio de pesquisas etnográficas possam se expressar, mostrar seus pontos de vista por uma linguagem não humana.

A impressão botânica é uma técnica recente, mas que está sendo aderida gradativamente a processos artísticos contemporâneos, principalmente ligados à vestimenta e à decoração, como uma forma de substituição de elementos não naturais em nossas casas e corpos. Essa técnica basicamente pode ser definida pelos seguintes processos: coletar e identificar plantas tintoriais, preparar fibras naturais por meio de mordentes ${ }^{12}$, enrolar tais plantas nesses tecidos utilizando bambus, canos ou outros suportes e fazer a fervura desses materiais em água. Ao abrir os tecidos, obtemos cores, formas e texturas extraídas naturalmente a partir dos materiais escolhidos. Porém, existem outros elementos que precisam ser observados para que possamos fazer uma boa impressão botânica em qualquer período do ano. E esse é o ponto principal da impressão botânica, apesar de a grande maioria das pessoas se limitar ao resultado final e não ao processo.

Tais elementos são invisíveis, "não racionais" e mudos. Normalmente, precisamos desenvolver nossa percepção, intuição, nosso olfato e nossa paciência para que os enxerguemos. É como pesquisar sobre a pesca de crustáceos, os afetados por barragens ou sobre os mangues: há sempre "algo a mais" que extrapola um saber-fazer, um "acidente" ou uma espécie. E é sobre esse "algo a mais" que também fala a impressão botânica.

Por meio da oficina que ministrei de forma colaborativa durante a VII ReACT, pude demonstrar por uma linguagem artística e não linear uma forma de registrar paisagens e uma forma de tentar compreender esse "algo a mais", essa "dança" - como diz Anna Tsing (2019) - que permeia os campos de inúmeras pesquisas antropológicas. Durante a oficina, relacionei alguns mordentes utilizados para a preparação de tecidos a estudos citados pelos pesquisadores que cocriaram essa oficina comigo, como acetato de ferro, sulfato de cobre e cal (que produzi por meio da queima e trituração de cascas de ostras e mariscos dos mangues).

A preparação dos mordentes é uma das etapas mais fundamentais, é o elemento que faz a "mágica acontecer", são as substâncias que conectam o mundo das plantas ao mundo dos humanos, é o que dá voz às plantas. Ou melhor, é o tradutor delas. Os mordentes são elementos extraídos dos ambientes e que receberam alterações químicas pelas mãos humanas. Enquanto as "plantas são plantas" e os "humanos são humanos", os mordentes habitam esses dois mundos. Estar presente no ato de fazer o mordente - "mordentar", como falamos - é uma forma de dispor-se a encontrar um ritmo para poder dançar com as plantas, é a porta de entrada para um mundo quase que inacessível. A "fazedura do mordente" se assemelha a cozinhar um bolo: pode "desandar" de acordo com o seu humor. Fazê-lo coletivamente, como fizemos durante a oficina, é um convite para confiar no outro, para colaborar.

Durante a oficina, utilizei plantas como Erva-baleeira (Cordia verbenácea), Aroeira (Schinus terebinthifolia) e Rabo-de-macaco, cascas de cebola, Grevilha (Grevílea-robusta) e Casuarina (Casuarina equisetifolia). Essas duas últimas são consideradas espécies invasoras, exóticas ou "perturbadoras". Pensar as plantas como "nativas ou exóticas" me faz refletir sobre a própria forma de reprodução desses seres. Será que eles se perpetuam através

12 Os mordentes são substâncias de origem vegetal ou mineral que servem para auxiliar a absorção dos corantes naturais feitos pela fibra. 
dos humanos, ou dos não humanos? Elas deixariam de ser "nativas" ou "exóticas" por causa desses fatores? Como a presença delas afeta uma determinada paisagem?

Podemos ir além de uma mera dicotomia entre um ponto ou outro. Pontos estes que limitam nossa capacidade de pensar a transformação, a perturbação e a interdependência entre inúmeras espécies. É transcendendo esse debate dúbio que é possível compreender sobre relações interespecíficas entre insetos, plantas, herbívoros, humanos, fungos e, futuramente, outros seres que ainda não conhecemos.

Um dia antes de a oficina ocorrer, me deparei com uma plantação imensa de flores cosmos ao lado do local em que teríamos a prática. Entusiasmada com a descoberta, fui coletá-las no dia seguinte junto com os integrantes da oficina. Chegando ao local, haviam cortado todas as flores que anteriormente estavam ali. Percebi que o jardineiro - ou quem as tiver cortado - assim como eu, apenas aplicou sua habilidade perante a paisagem que ele interagia. Paisagem que se não fosse alterada por ele, seria alterada por nós, ou por insetos, pelo vento, pela chuva ou pela seca.

Figura 5 - Obra coletiva feita durante a oficina na VII ReACT

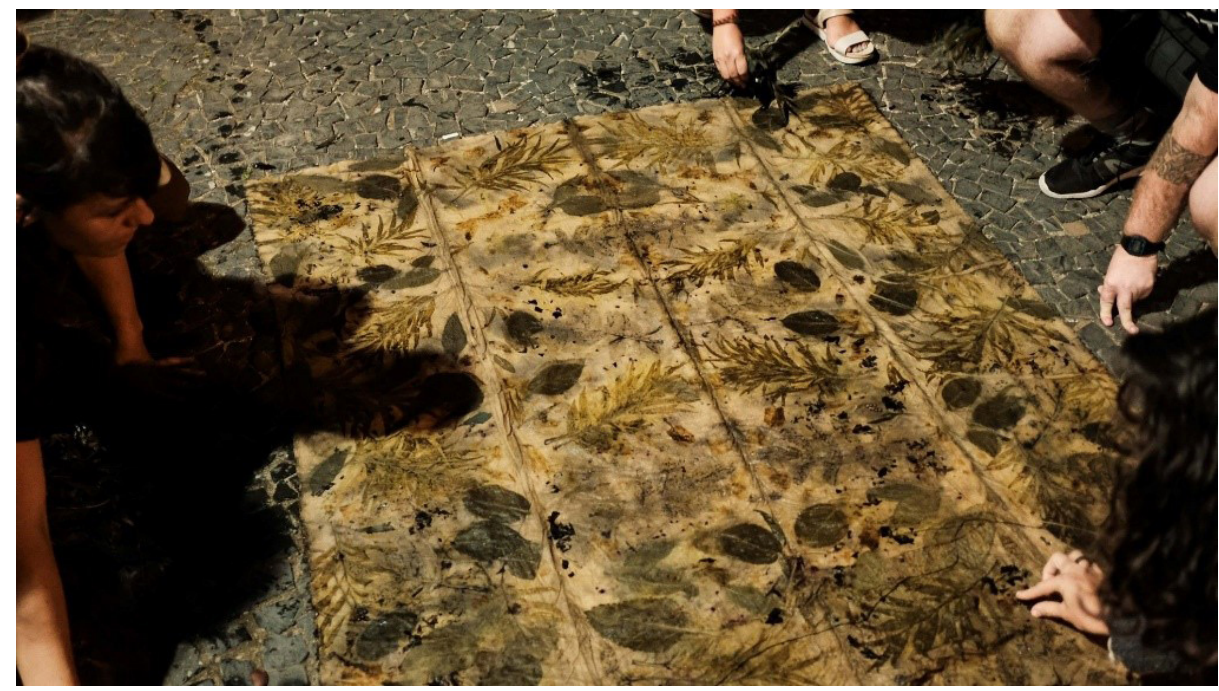

Fonte: Acervo de Natália Seeger (2019)

É nítido que as plantas possuem formas de se comunicar muito peculiares e praticamente invisíveis aos olhos humanos, olhos que sempre lutam a encontrar e relacionar aspectos humanos em tudo que se relacionam. "Humanizar" torna-se um termo positivo na nossa visão. Um desses aspectos quase que imperceptível - por ficar embaixo da terra - é a relação micorrízica entre fungos e plantas. Essa relação ocorre por meio de uma "malha" de raízes e hifas que se entrelaçam embaixo da terra, fazendo com que plantas e fungos ajudem uns aos outros. É uma simbiose, uma cooperação entre duas espécies distintas que são interdependentes e que fazem com que ambas sobrevivam em paisagens não tão amigáveis assim. Paisagens conturbadas. Atualmente, algumas pessoas chamam essas relações de "internet das plantas/fungos".

Nós humanos temos muito a aprender com essa relação milenar, que apenas pode ser vista com outros olhos: com olhos de planta - ou de fungo. Uma espécie de fungo ectomicorrízico chamado Pisolithus tinctorius, que faz troca de nutrientes por meio da 
conexão de suas hifas às raízes de Pinus e diversas espécies de Eucalipto, foi introduzida à nossa panela de fervura da água turva durante a oficina (essa espécie foi obtida por meio de uma doação do Micolab/UFSC). Esse ato, além de render bons debates, selou a rede de interconexões entre mundos distintos, perturbados, cooperativos e que, acima de tudo, sobrevivem, recriando paisagens.

Tal "rede de interconexões" pode ser vista também em outros materiais utilizados na oficina, como a rede de pesca de poliamida. Em Itajaí, SC, os pescadores a chamam de "malha", e dizem que serve para "matar peixe". Para artesãos de Florianópolis, SC como a Nara Guichon - a malha serve para a criação de colares e bolsas. Para Tim Ingold, essa malha pode ter outros significados. Para Bruno Latour, essa malha seria diferente e se chamaria "rede" (DUARTE, 2018). E para nós, ela serviu para amarrar a tela que fizemos coletivamente.

Compartilhei na oficina o relato de uma observação que fiz acerca de alguns ciclos das plantas. Fiz esse estudo durante o ano de 2018, quando testei um mesmo tecido com diferentes mordentes em diferentes estações do ano e lunações. Dispus-me a aprender a dançar com as plantas e com os ciclos que as influenciam e pude observar que mesmo utilizando um mesmo mordente, em um mesmo tecido, em uma mesma forma de fervura, havia diferenças pictóricas nos resultados finais. O que as plantas saídas das fervuras da água turva estavam querendo me dizer? Percebi que, assim como os seres humanos, as plantas (aqui, refiro-me às plantas utilizadas no processo de impressão botânica) também recebem influência dos ciclos lunares e das estações do ano (sem contar outros fatores como a química do solo, a poluição do ar, o pH da terra, a quantidade de tanino que a planta possui, etc.). Sua seiva está em constante movimento, suas substâncias estão completamente alinhadas aos ciclos da natureza. Se ela está em época de frutificação, haverá mais tanino. Se estiver na lua nova, sua seiva líquida estará nas raízes. Se estiver no outono, suas folhas começarão a cair. Sem contar a relação que as plantas possuem entre si. Todos esses ciclos alteram os resultados obtidos por meio da técnica de impressão botânica, influenciando a intensidade dos tons que as plantas liberam.

Tais fatores podem ser óbvios para um botânico ou para um estudioso de neurobiologia das plantas, mas para uma antropóloga tintureira nem tanto. O grande erro, já comentado anteriormente, é focarmos no resultado final - seja em um trabalho artesanal, ou em um trabalho acadêmico - muitas vezes, essa ânsia de ver a "coisa" pronta leva-nos a não enxergar o que realmente precisamos ver.

Esses fatores sutis, percebidos por causa de testes, observações, treino do olhar e percepções, trouxe-me para uma posição de aprendiz perante as plantas, uma forma de ouvi-las por meio de seus movimentos quase que imperceptíveis, muito diferente dos movimentos humanos. Foi necessária uma técnica artesanal para que eu aprendesse a "dançar com as plantas" e poder propor isso pelas vivências. Fazer impressão botânica é um convite a descolonizar nosso olhar, para que enxerguemos por outros ângulos aqueles movimentos que anteriormente pareciam não existir. Mesmo não focando no resultado final, a tela produzida coletivamente durante a oficina agregou elementos que remeteram a várias paisagens existentes pelo Brasil, paisagens que estão em constantes (des)construções e que foram trazidas durante a oficina. 


\section{Entre Colaborações: algumas considerações finais}

A oficina de pesquisa da qual demos notícia neste artigo apresentou ao leitor cinco experiências diversas de pesquisas que envolvem colaborações entre humanos e não humanos em paisagens do "tempo das catástrofes". As quatro primeiras experiências falam de engajamentos de pesquisadores com coletividades atingidas de forma específica por processos de destruição e de precarização de seus modos de existir.

No caso do Rio Doce, as consequências permanentes e continuadas do rompimento da barragem de resíduos minerais se desdobram em novas situações perversas de supressão de direitos à reparação. A ação do grupo de pesquisadores produz com os atingidos mecanismos artístico-políticos de mobilização reflexiva. No Rio Goiana, a proteção legal, no formato de Reserva Extrativista, dos manguezais habitados por diferentes espécies de caranguejos e por pescadores artesanais não garante imediatamente o fim dos processos de precarização e de contaminação. Nesse contexto, os pescadores, os pesquisadores e os gestores públicos tentam colaborar, por meio dos espaços institucionais e de outras formas, para evitar situações catastróficas de poluição e de desregulamentação socioambiental.

Nos manguezais de São Francisco do Conde, a terceira experiência relatada, quilombolas se aliam a professores e a alunos de uma universidade pública recémestabelecida em incursões ecopedagógicas aos dilemas da contaminação dos manguezais e do racismo ambiental. Nessas experiências, a universidade se abre a aprender com os movimentos sociais, as metodologias e as estratégias de uma pedagogia socioambiental da paisagem. Na quarta experiência apresentada, em meio aos conflitos cosmopolíticos gerados pelas ações de barrageamento do Rio Tapajós, indígenas Munduruku e seus aliados produzem uma delicada e sui generis comunicação cartográfica sobre as ameaças a seu território construindo um "Mapa da vida", que se contrapõe às estratégias de morte praticadas pela proliferação de construções de hidrelétricas na Amazônia.

A última experiência apresentada, desenvolvida em uma segunda parte da oficina por Natália, traz um contraponto produtivo às demais experiências. Se as narrativas apresentadas por Cristiana, Pedro, Rafael e Thiago indicam a atuação de pesquisadores produzindo conhecimento colaborativo em situações drásticas, Natália experimenta um conhecimento colaborativo nas malhas da impressão botânica que ressignifica artesanalmente tecidos em água, com extratos botânicos, animais e minerais em uma prática que nos ensina a "dançar com as plantas" nas margens do tempo das catástrofes.

Ouvir o apito do trem, afundar os pés no mangue, atravessar cercas, mapear o fim do mundo e imprimir plantas como formas de colaboração e de fazer parentes (HARAWAY, 2016) e de dançar em meio à perturbação.

\section{Agradecimentos}

O presente artigo foi escrito de forma colaborativa e teve apoio da Universidade Federal do Amazonas e da Coordenação de Aperfeiçoamento de Pessoal de Nível Superior. 


\section{Referências}

BALLESTERO, Andrea. The Anthropology of Water. Annual Review of Anthropology, [s.l.], v. 48, p. $405-421,2019$.

BANIWA, Gersem. Antropologia indígena: o caminho da descolonização e da autonomia indígena. In: $26^{\mathrm{a}}$ REUNIÃO BRASILEIRA DE ANTROPOLOGIA, realizada entre os dias $1^{\circ} \mathrm{e}$ 4 de junho de 2008, Porto Seguro, Bahia, Brasil. Anais [...]. Porto Seguro, BA, 2008.

BUTI, Rafael Palermo. O Gaiamum Petroleiro, o Meio Ambiente, o Quilombo e o Manquintal: notas sobre (des)fazer mundos nas paisagens de manguezal no Recôncavo da Bahia. In: VII REUNIÃO DE ANTROPOLOGIA DA CIÊNCIA E DA TECNOLOGIA, Florianópolis, 2019. Anais […]. Florianópolis, 2019.

CARDOSO, Thiago Mota. Malhas cartográficas técnicas, conhecimentos e cosmopolítica do ato de mapear territórios indígenas. In: V REUNIÃO DE ANTROPOLOGIA DA CIÊNCIA E TECNOLOGIA, Campinas, 2014. Anais [...]. Campinas, São Paulo, v. 1, n. 1, 2014.

CHOY, Timothy K. et al. A new form of collaboration in cultural anthropology: Matsutake worlds. American Ethnologist, [S.l.], v. 36, n. 2, p. 380-403, 2009.

DANOWSKI, Deborah; VIVEIROS DE CASTRO, Eduardo. Há mundo por vir? Ensaio sobre os medos e os fins. Desterro [Florianópolis]: Cultura e Barbárie: Instituto Socioambiental, 2014.

DEWEY, John. Art as experience. New Yourk, USA: Penguin, 2005.

DUARTE, Natalia Seeger. Redes, malhas e mãos: o processo artesanal da rede de pesca do mar ao ateliê. 2018. TCC (Graduação) - Universidade Federal de Santa Catarina, Centro de Filosofia e Ciências Humanas, Curso de Ciências Sociais, Florianópolis, SC, 2018.

GADOTTI, Moacir. Pedagogia da terra: ecopedagogia e educação sustentável. Buenos Aires: Consejo Latinoamericano de Ciencias Sociales (CLACSO), 2001.

GLOWCZEWSKI, Barbara. Resisting the disaster: between exhaustion and creation. Spheres: Journal for Digital Cultures, [s.l.], v. 2, p. 1-19, 2015.

HARAWAY, Donna et al. Anthropologists are talking-about the Anthropocene. Ethnos, [s.l.], v. 81, n. 3, p. 535-564, 2016.

HARAWAY, Donna J. Staying with the trouble: Making kin in the Chthulucene. Duke, EUA: Duke University Press, 2016.

HARAWAY, Donna. The Companion Species Manifesto: dogs, people, and significant otherness. Chicago: Prickly Paradigm Press, 2003.

HINKSON, Melinda. Precarious placemaking. Annual Review of Anthropology, [s.l.], v. 46, p. 49-64, 2017.

INGOLD, Tim. Estar vivo: ensaios sobre movimento, conhecimento e descrição. São Paulo: Vozes, 2015.

KRENAK, Ailton. Ideias para adiar o fim do mundo. São Paulo: Editora Companhia das Letras, 2019.

LATOUR, Bruno. Anthropology at the time of the Anthropocene: a personal view of what is to be studied. In: LATOUR, Bruno. The anthropology of sustainability. New York: Palgrave Macmillan, 2017. p. 35-49.

MATHEWS, Andrew S. Anthropology and the Anthropocene: Criticisms, Experiments, and Collaborations. Annual Review of Anthropology, [s.l.], v. 49, 2020.

MIRZOEFF, Nicholas. It's not the Anthropocene, It's the White supremacy scene; or, the geological color line. In: MIRZOEFF, Nicholas. After Extinction. Minnesota: University of Minnesota Press, 2018. p. 123-149. 
MOURA, Margarida Maria. Liberdade e Igualdade: reflexões sobre campesinato sertanejo e política. Cadernos CERU, [s.l.], n. 3, série 11, 1991.

PINTO, Luiz. A. C. Recôncavo: Laboratório de uma experiência humana. In: AZEVEDO BRANDÃO, Maria de (org.). Recôncavo da Bahia: sociedade e economia em transição. Salvador: Fundação Casa Jorge Amado; Academia de Letras da Bahia; Universidade Federal da Bahia, 1998. p. 101-183.

POVINELLI, Elizabeth A. Geontologies: a requiem to late liberalism. Duke, EUA: Duke University Press, 2016.

RAMALHO, Cristiano. A formação histórica da pesca artesanal: origens de uma cultura do trabalho apoiada no sentimento de arte e de liberdade. Cadernos de Estudos Sociais, [s.l.], v. 24, n. 2, 2008.

RAMALHO, Cristiano. O colapso da pesca artesanal no litoral de Pernambuco. Revista Coletiva - Diversidade Socioambiental, [s.l.], n. 11, 2020. Disponível em: coletiva.org/ diversidade-socioambienta-n-11. Acesso em: 4/6/, 2020.

RAPPAPORT, Joanne. Beyond participant observation: Collaborative ethnography as theoretical innovation. Collaborative Anthropologies, [s.l.], v. 1, n. 1, p. 1-31, 2008.

SILVEIRA, Pedro C. B.; BUTI, Rafael. A vida e a morte dos guaiamuns: antropologia nos limites dos manguezais. Anuário Antropológico, [s.l.], v. 45, n. 1, 2020.

SILVEIRA, Pedro C. B. et al. Estuário, paisagem-fluxo de pescadores artesanais. Iluminuras, [s.l.], v. 14, p. 304-323, 2013.

STENGERS, Isabelle. No tempo das catástrofes. São Paulo: Cosac Naify, 2015. p. 71.

TSING, Anna. Viver nas ruínas: paisagens multiespécies no Antropoceno. Brasília, DF: IEB Mil Folhas, 2019.

TSING, Anna Lowenhaupt; MATHEWS, Andrew S.; BUBANDT, Nils. Patchy Anthropocene: Landscape Structure, Multispecies History, and the Retooling of Anthropology: an Introduction to Supplement 20. Current Anthropology, [s.l.], v. 60, n. S20, p. S186-S197, 2019.

\section{Thiago Mota Cardoso}

Doutor em Antropologia Social. Professor do Departamento de Antropologia (DAN) da Universidade Federal do Amazonas (UFAM).

Endereço profissional: Campus Universitário Senador Arthur Virgílio Filho, Bloco Administrativo n. 3 Pavilhão Uatumã, Setor Norte, Coroado, Manaus, AM. CEP: 69077-000.

E-mail: thi.motacardoso@gmail.com; thiagocardoso@ufam.edu.br

ORCID: https://orcid.org/0000-0002-7220-7487

\section{Cristiana Losekann}

Doutora em Ciência Política (UFRGS). Professora do Departamento de Ciências Sociais e do Programa de Pós-Graduação em Ciências Sociais da Universidade Federal do Espírito Santo (UFES).

Endereço profissional: Avenida Fernando Ferrari, n. 814, Campus Universitário Goiabeiras, Prédio Bárbara Weinberg, sala 314, Vitória, ES. CEP: 29075-910.

E-mail: cristiana.losekann@ufes.edu.br

ORCID: https://orcid.org/0000-0002-9043-4034 


\section{Rafael Palermo Buti}

Doutor em Antropologia Social pela UFSC. Professor do Instituto de Humanidades e Letras da Universidade da Integração Internacional da Lusofonia Afro-Brasileira (Unilab).

Endereço profissional: Unilab Campus Malês, Av. Juvenal Eugênio Queiroz, s/n, Centro, São Francisco do Conde, BA. CEP: 43900-000.

E-mail: rafaelpbuti@gmail.com

ORCID: https://orcid.org/0000-0002-3505-3095

\section{Pedro Castelo Branco Silveira}

Doutor em Ciências Sociais (Unicamp). Pesquisador da Fundação Joaquim Nabuco (FUNDAJ).

Endereço profissional: Fundaj - Diretoria de Pesquisas Sociais, Rua Dois Irmãos, n. 92, Apipucos, Recife, PE. CEP: 52071-440.

E-mail:pedrocbsilveira@gmail.com

ORCID: https://orcid.org/0000-0003-1507-0047

\section{Natália Seeger Duarte}

Graduanda em Ciências Sociais (UFSC). Artista têxtil, professora e pesquisadora independente. Endereço profissional: Rua Tenente Silveira, n. 675, Centro, Florianópolis, SC. CEP: 88010-301. E-mail: nataliaseegerd@gmail.com

ORCID: https://orcid.org/0000-0003-1507-0047

\section{Diego Kern Lopes}

Doutor em Artes - Processos Artísticos Contemporâneos (UERJ). Artista e pesquisador associado ao Organon - Núcleo de Estudo, Pesquisa e Extensão em Mobilizações Sociais da Universidade Federal do Espírito Santo (UFES).

Endereço profissional: Avenida Fernando Ferrari, n. 814, Campus Universitário Goiabeiras, Prédio Bárbara Weinberg, sala 314, Vitória, ES. CEP: 29075-910.

E-mail:diegokernlopes@gmail.com

ORCID: https://orcid.org/0000-0003-2431-0778

\section{Como referenciar este artigo:}

CARDOSO, Thiago Mota et al. Vidas Precárias em Águas Turvas: antropologia colaborativa nas ruínas do Antropoceno. Ilha - Revista de Antropologia, Florianópolis, v. 23, n. 1, p. 97-126, 2021. 